\title{
Respon Mahasiswa Terhadap Pembelajaran Statistika dalam Aspek Kognitif, Afektif dan Psikomotorik
}

\author{
Abdul Wahab ${ }^{*}$, Junaedi $^{2}$ \\ ${ }^{1}$ Universitas Muslim Indonesia \\ ${ }^{2}$ Institut Agama Islam DDI Polewali Mandar \\ *email: abdulwahab79@umi.ac.id \\ (Received: 03-02-2021; Reviewed: 07-02-2021; Accepted: 17-02-2021)
}

\begin{abstract}
Abstrak
Masalah utama yang diangkat dalam penelitian ini adalah "bagaimana respon mahasiswa terhadap pembelajaran statistika di tinjau dari aspek kognitif, aspek afektif, dan aspek psikomotorik mahasiswa. Jenis penelitian yang digunakan adalah penelitian kuantitatif dengan sampel sebanyak 35 mahasiswa program studi Pendidikan Agama Islam Fakultas Agama Islam Universitas Muslim Indonesia, instrumen yang digunakan adalah lembar angket respon mahasiswa terhadap pembelajaran statistika meliputi aspek kognitif sebanyak 6 item, aspek afektif 3 item dan aspek psikomotorik sebanyak 4 item pernyataan, data dianalisis dengan menggunakan persentase dan nilai rata-rata. Hasil penelitian menunjukkan bahwa respon mahasiswa di tinjau dari aspek kognitif menunjukkan respon positif sebesar $60 \%$, aspek afektif sebesar $80 \%$, dan aspek psikomotorik sebesar $72 \%$, sehingga dapat disimpulkan bahwa respon mahasiswa terhadap pembelajaran statistika berada pada respon yang positif dengan menunjukkan kualitas pembelajaran yang menarik.
\end{abstract}

Kata Kunci: respon mahasiswa, aspek kognitif, afektif, psikomotorik

\begin{abstract}
The main problem raised in this study is "how students respond to learning statistics in terms of cognitive aspects, affective aspects, and psychomotor aspects of students. The type of research used is quantitative research with a sample of 35 students of the Islamic Religious Education study program, the Faculty of Islamic Religion, Muslim University of Indonesia, the instrument used is a questionnaire sheet of student responses to learning statistics including 6 cognitive aspects, 3 items of affective aspects and as many psychomotor aspects 4 statement items, data were analyzed using percentages and average values. The results showed that student responses in terms of cognitive aspects showed a positive response of $60 \%$, affective aspects of $80 \%$, and psychomotor aspects of $72 \%$, so it can be concluded that student responses to learning statistics are in a positive response by showing the quality of learning that is interesting.
\end{abstract}

Keywords: student response, cognitive, affective, psychomotor aspects

\section{Pendahuluan}

Belajar merupakan kegiatan berproses dan unsur yang sangat fundamental dalam setiap jenjang pendidikan. Dalam keseluruhan proses pendidikan, kegiatan belajar merupakan kegiatan yang paling pokok dan penting dalam keseluruhan proses pendidikan (Syah, 2013). Belajar adalah proses atau usaha yang dilakukan tiap individu untuk memperoleh suatu perubahan tingkah laku baik dalam bentuk pengetahuan, keterampilan maupun sikap dan nilai yang positif sebagai pengalaman untuk mendapatkan sejumlah kesan dari bahan yang telah dipelajari. Kegiatan belajar tersebut dapat dilakukan di kampus, di laboratorium, di rumah, dan di tempat lain (Slameto, 2013). 
Peranan statistika dalam era globalisasi kehidupan yang modern sekarang ini, membantu memudahkan kehidupan manusia (delMas, 2002). Lebih jelasnya, menurut (Tjalla, 2010) bahwa peranan statistika antara lain terlihat pada: (1) dalam kehidupan sehari-hari, (2) dalam kegiatan ilmiah, (3) dalam kegiatan proses belajar mengajar, dan (4) dalam kegiatan ilmu pengetahuan. Mengingat peranan statistika, maka selayaknya penanganan terhadap proses pembelajaran statistika perlu dilakukan dengan baik. Penanganan yang dimaksud adalah mengarahkan proses pembelajaran ke arah pencapaian tujuan pembelajaran statistika yang pada akhirnya pencapaian tujuan tersebut sejalan dengan materi yang disajikan. Oleh karena itu, statistika perlu dibekalkan kepada mahasiswa dan perlu adanya usaha peningkatan kualitas pembelajaran statistika di perguruan tinggi (Cobb, 1992).

Berkaitan dengan pembelajaran statistika secara khusus dan pembelajaran secara umum, (Sanjaya, 2008), mengemukakan bahwa pembelajaran di Indonesia sebaiknya memenuhi empat pilar pendidikan yang dirumuskan UNESCO, yaitu: (1) Learning to know, mengandung pengertian bahwa belajar itu pada dasarnya tidak hanya berorientasi kepada produk atau hasil belajar, akan tetapi juga harus berorientasi kepada proses belajar, (2) Learning to do, mengandung pengertian bahwa belajar itu bukan hanya sekedar mendengar dan melihat dengan tujuan akumulasi pengetahuan, tetapi belajar untuk berbuat dengan tujuan akhir penguasaan kompetensi yang sangat diperlukan dalam era persaingan global, (3) Learning to be, mengandung pengertian bahwa belajar adalah membentuk manusia yang "menjadi dirinya sendiri", (4) Learning to live together, adalah belajar untuk bekerja sama.

Pembelajaran statistika yang diterapkan pada perguruan tinggi terdiri atas fakta, konsep atau asumsi yang berangkat dari realitas kehidupan, maka untuk memahaminya diperlukan upaya kreatif dalam memikirkan, menganalisis, dan mengaplikasikan dalam berbagai situasi nyata (Moore, 1997; Wahab, 2017). Pembelajaran statistika harus dikemas sedemikian rupa supaya menarik dengan menggunakan strategi, pendekatan, metode ataupun teknik mengajar yang dapat menumbuhkan semangat mahasiswa dalam belajar, memudahkannya dalam memahami dan mengerti apa yang disajikan sehingga menciptakan hasil belajar yang optimal (Moore, 1997; Tiro, 2017).

Peningkatan kualitas proses pembelajaran statistika di perguruan tinggi dapat dilakukan dengan berbagai strategi, salah satu strateginya adalah melalui metode pembelajaran aktif. Dalam penelitian ini alternatif yang dapat ditempuh dengan mendapatkan respon mahasiswa dalam pembelajaran aktif di tinjau dari aspek kognitif, afektif, dan psikomotorik mahasiswa (Bruce et al., 2011).

\section{Metode}

Jenis penelitian yang digunakan adalah penelitian kuantitatif (Sugiyono, 2013), berdasarkan tujuan utama penelitian ini adalah mendapatkan hasil respon mahasiswa pada program studi Pendidikan Agama Islam Fakultas Agama Islam Universitas Muslim Indonesia sebanyak 35 
mahasiswa pada tahun akademik 2019/2020 terhadap pembelajaran mata kuliah statistika pendidikan di tinjau dari aspek kognitif, aspek afektif, dan aspek psikomotorik.

Instrumen yang digunakan dalam penelitian ini adalah instrumen berupa lembar angket respon mahasiswa terhadap pembelajaran statistika meliputi aspek kognitif sebanyak 6 item, aspek afektif 3 item dan aspek psikomotorik sebanyak 4 item pernyataan. Data diperoleh melalui skor angket respon mahasiswa yang diolah secara kuantitatif, kemudian dianalisis dengan menggunakan persentase dan nilai rata-rata (Wahab, 2013).

Pemberian angket terhadap mahasiswa dimaksudkan untuk mendapatkan informasi tentang respon mahasiswa terhadap pembelajaran statistika dengan memberikan angket kepada 35 mahasiswa program studi pendidikan agama Islam Universitas Muslim Indonesia. Aspek-aspek yang ditanyakan dalam angket, yaitu; respon mahasiswa terhadap aspek kognitif, aspek afektif, dan aspek psikomotorik.

Persentase pengamatan tentang respon mahasiswa yaitu frekuensi setiap aspek pengamatan dibagi dengan banyaknya frekuensi semua aspek pengamatan dikali 100\% (Wahab et al., 2018). Kriteria respon mahasiswa (RM) terhadap pembelajaran statistika dalam (Arikunto, 2016; Wahab, 2017) sebagai berikut:

Tabel 1. Kategori Respon Mahasiswa terhadap Pembelajaran Statistika

\begin{tabular}{cc}
\hline Rentang Skor & Kategori \\
\hline $81 \% \leq \mathrm{RM} \leq 100 \%$ & Sangat Menarik $(\mathrm{SM})$ \\
$61 \% \leq \mathrm{RM}<80 \%$ & Menarik $(\mathrm{M})$ \\
$41 \% \leq \mathrm{RM}<60 \%$ & Cukup Menarik $(\mathrm{CM})$ \\
$21 \% \leq \mathrm{RM}<40 \%$ & Kurang Menarik $(\mathrm{KM})$ \\
$0 \% \leq \mathrm{RM}<20 \%$ & Tidak Menarik $(\mathrm{TM})$ \\
\hline
\end{tabular}

Berdasarkan kategori tersebut, maka respon mahasiswa terhadap pembelajaran statistika memenuhi kategori respon positif apabila respon mahasiswa berada dalam kategori menarik atau sangat menarik.

\section{Hasil}

Hasil angket respon mahasiswa terhadap pelaksanaan pembelajaran statistika sebagai berikut;

\section{Aspek kognitif}

Secara ideal bahwa skor tentang respon mahasiswa terhadap pembelajaran statistika yang berhubungan dengan aspek kognitif, yaitu; skor terendah 6 dan skor tertinggi 24. Berdasarkan hasil analisis deskriptif, setelah di konversi ke skor 100, maka diperoleh skor terendah 33 dan skor tertinggi 83, harga mean sebesar 62,1 dengan standar deviasi sebesar 13,0. Untuk mengetahui distribusi frekuensi masing-masing kategori (Wahab et al., 2021) dapat dilihat pada Tabel 2 berikut. 
Tabel 2. Distribusi Frekuensi Respon Mahasiswa pada Aspek Kognitif

\begin{tabular}{cccc}
\hline Kategori & Skor Interval & Frekuensi & $\begin{array}{c}\text { Persentase } \\
(\boldsymbol{\%})\end{array}$ \\
\hline Sangat Menarik & $81-100$ & 2 & 6 \\
Menarik & $61-80$ & 19 & 54 \\
Cukup Menarik & $41-60$ & 12 & 34 \\
Kurang Menarik & $21-40$ & 2 & 6 \\
Tidak Menarik & $0-20$ & 0 & 0 \\
\hline \multicolumn{2}{r}{ Jumlah } & 35 & 100 \\
\hline
\end{tabular}

Berdasarkan distribusi frekuensi pada Tabel 2, dapat dijelaskan bahwa dari 35 responden yang disurvei tentang respon mahasiswa terhadap pembelajaran statistika dalam hubungannya dengan aspek kognitif terdapat 2 responden (6\%) memberi respon sangat menarik, 19 responden (54\%) memberi respon menarik, 12 responden (34\%) memberi respon cukup menarik, dan 2 responden (6\%) memberi respon kurang menarik. Ini berarti, dari 35 responden yang disurvei kebanyakan mereka menyatakan bahwa pembelajaran statistika menarik dalam hubungannya dengan aspek kognitif, karena kebanyakan mahasiswa senang dengan metode dosen dalam menjelaskan pengetahuan dan memberikan aplikasi serta menganalisis konsep statistika, sehingga dapat disimpulkan bahwa pembelajaran statistika pada umumnya berada pada kualitas menarik dalam hubungannya dengan aspek kognitif mahasiswa.

Gambaran respon mahasiswa terhadap pembelajaran statistika dalam hubungannya dengan aspek kognitif dapat dilihat pada Gambar 1.

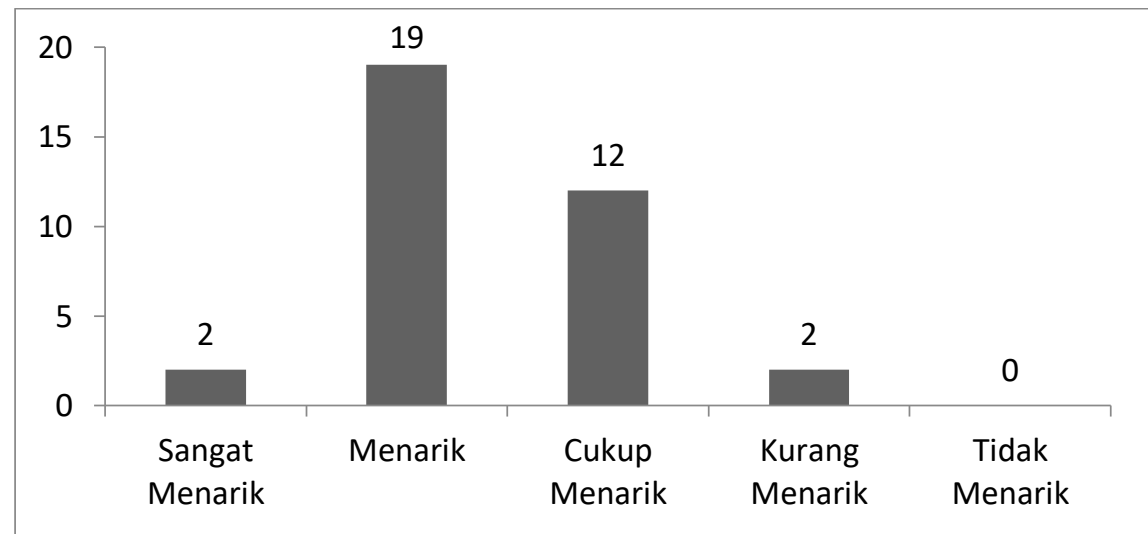

Gambar 1. Diagram Respon Mahasiswa pada Aspek Kognitif

\section{Aspek afektif}

Secara ideal bahwa skor tentang respon mahasiswa terhadap pembelajaran statistika yang berhubungan dengan aspek afektif, yaitu; skor terendah 3 dan skor tertinggi 12. Berdasarkan hasil analisis deskriptif, setelah di konversi ke skor 100, diperoleh skor terendah 50 dan skor tertinggi 92, 
harga mean sebesar 72,4 dengan standar deviasi sebesar 11,9. Untuk mengetahui distribusi frekuensi masing-masing kategori dapat dilihat pada Tabel 3.

Tabel 3. Distribusi Frekuensi Respon Mahasiswa pada Aspek Afektif

\begin{tabular}{cccc}
\hline Kategori & Skor Interval & Frekuensi & Persentase (\%) \\
\hline Sangat Menarik & $81-100$ & 10 & 29 \\
Menarik & $61-80$ & 18 & 51 \\
Cukup Menarik & $41-60$ & 7 & 20 \\
Kurang Menarik & $21-40$ & 0 & 0 \\
Tidak Menarik & $0-20$ & 0 & 0 \\
\hline Jumlah & 35 & 100
\end{tabular}

Berdasarkan distribusi frekuensi pada Tabel 3, dapat dijelaskan bahwa dari 35 responden yang disurvei tentang respon mahasiswa terhadap pembelajaran statistika dalam hubungannya dengan aspek afektif terdapat 10 responden (29\%) memberi respon sangat menarik, 18 responden (51\%) memberi respon menarik, dan 7 responden (20\%) memberi respon cukup menarik. Ini berarti, dari 35 responden yang disurvei kebanyakan mereka menyatakan bahwa pembelajaran statistika menarik dalam hubungannya dengan aspek afektif, karena kebanyakan mahasiswa senang dengan metode dosen dalam melatih sikap santun menghargai pendapat mahasiswa, sehingga dapat disimpulkan bahwa pembelajaran statistika pada umumnya berada pada kualitaas menarik dalam hubungannya dengan aspek afektif mahasiswa. Gambaran respon mahasiswa terhadap pembelajaran statistika dalam hubungannya dengan aspek afektif dapat dilihat pada Gambar 2.

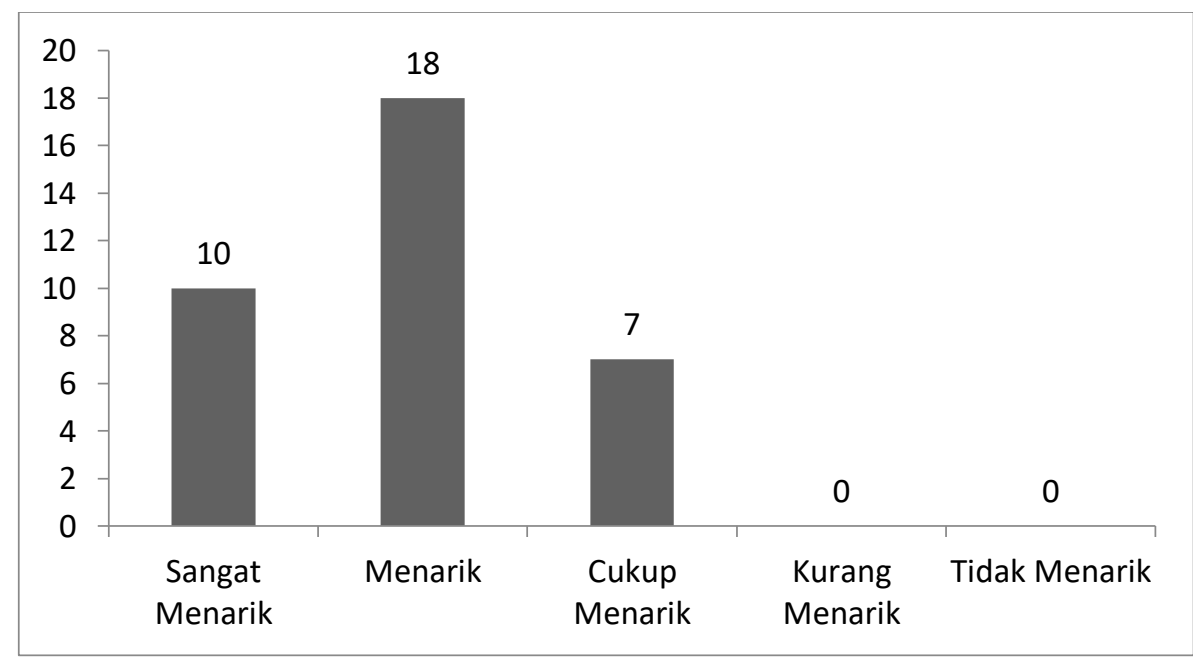

Gambar 2. Diagram Respon Mahasiswa pada Aspek Afektif

3. Aspek psikomotorik

Secara ideal bahwa skor tentang respon mahasiswa terhadap pembelajaran statistika yang berhubungan dengan aspek psikomotorik, yaitu; skor terendah 4 dan skor tertinggi 16. Berdasarkan hasil analisis deskriptif, setelah di konversi ke skor 100, diperoleh skor terendah 31 dan skor tertinggi 
94, harga mean sebesar 66,1 dengan standar deviasi sebesar 14,6. Untuk mengetahui distribusi frekuensi masing-masing kategori dapat dilihat pada Tabel 4.

Tabel 4 Distribusi Frekuensi Respon Mahasiswa pada Aspek Psikomotorik

\begin{tabular}{cccc}
\hline Kategori & Skor Interval & Frekuensi & Persentase (\%) \\
\hline Sangat Menarik & $81-100$ & 8 & 23 \\
Menarik & $61-80$ & 17 & 49 \\
Cukup Menarik & $41-60$ & 9 & 26 \\
Kurang Menarik & $21-40$ & 1 & 3 \\
Tidak Menarik & $0-20$ & 0 & 0 \\
\hline \multicolumn{2}{c}{ Jumlah } & 35 & 100 \\
\hline
\end{tabular}

Berdasarkan distribusi frekuensi pada Tabel 4, dapat dijelaskan bahwa dari 35 responden yang disurvei tentang respon mahasiswa terhadap pembelajaran statistika dalam hubungannya dengan aspek psikomotorik terdapat 8 responden (23\%) memberi respon sangat menarik, 17 responden (49\%) memberi respon menarik, 9 responden (26\%) memberi respon cukup menarik, dan 1 responden (3\%) memberi respon kurang menarik. Ini berarti, dari 35 responden yang disurvei kebanyakan mereka menyatakan bahwa pembelajaran statistika menarik dalam hubungannya dengan aspek psikomotorik, karena kebanyakan mahasiswa senang dengan metode dosen dalam melatih kemampuan menyesuaikan diri dengan pembelajaran statistika, sehingga dapat disimpulkan bahwa pembelajaran statistika pada umumnya berada pada kualitas menarik dalam hubungannya dengan aspek psikomotorik mahasiswa. Gambaran respon mahasiswa terhadap pembelajaran statistika dalam hubungannya dengan aspek psikomotorik dapat dilihat pada Gambar 3.

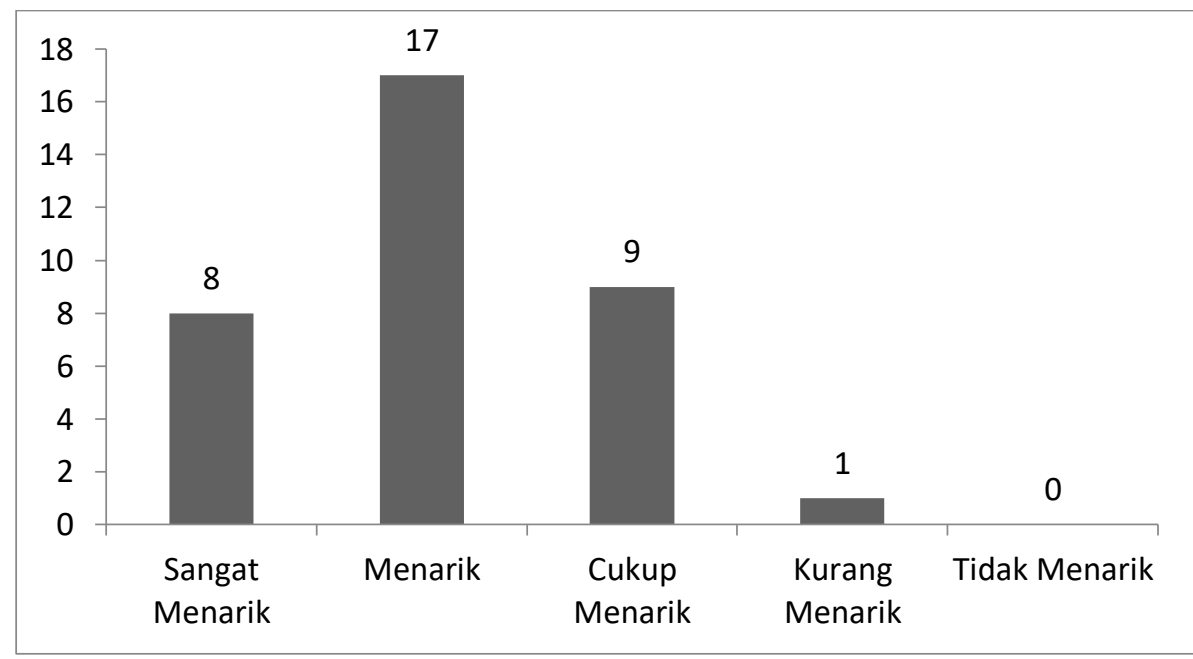

Gambar 3. Diagram Respon Mahasiswa pada Aspek Psikomotorik

4. Skor total respon mahasiswa terhadap pembelajaran statistika

Respon mahasiswa terhadap pembelajaran statistika terdiri dari 4 aspek dan 23 butir pernyataan, yaitu; 6 butir pernyataan aspek kognitif, 3 butir pernyataan aspek afektif, 4 butir pernyataan aspek psikomotorik, dan 10 butir pernyataan aspek kemampuan literasi statistika. 
Secara ideal bahwa skor tentang respon mahasiswa terhadap pembelajaran statistika, yaitu: skor terendah 23 dan skor tertinggi 92. Berdasarkan hasil analisis statistik deskriptif, setelah di konversi ke skor 100, diperoleh skor terendah 52 dan skor tertinggi 84, harga mean sebesar 65,4 standar deviasi sebesar 9,4. Untuk mengetahui distribusi frekuensi masing-masing kategori dapat dilihat pada Tabel 5.

Tabel 5. Distribusi Frekuensi Respon Mahasiswa terhadap Pembelajaran Statistika

\begin{tabular}{cccc}
\hline Kategori & Skor Interval & Frekuensi & Persentase (\%) \\
\hline Sangat Menarik & $81-100$ & 2 & 6 \\
Menarik & $61-80$ & 21 & 60 \\
Cukup Menarik & $41-60$ & 12 & 34 \\
Kurang Menarik & $21-40$ & 0 & 0 \\
Tidak Menarik & $0-20$ & 0 & 0 \\
\hline \multicolumn{2}{c}{ Jumlah } & 35 & 100 \\
\hline
\end{tabular}

Berdasarkan distribusi frekuensi pada Tabel 5, dapat dijelaskan bahwa dari 35 responden yang disurvei tentang respon mahasiswa terhadap pembelajaran statistika terdapat 2 responden (6\%) memberi respon sangat menarik, 21 responden (60\%) memberi respon menarik, dan 12 responden (34\%) memberi respon cukup menarik. Ini berarti, dari 35 responden yang disurvei kebanyakan mereka menyatakan bahwa pembelajaran statistika menarik, karena mahasiswa senang dengan metode dosen dalam memberi penjelasan dan pemahaman tentang statistika, sehingga dapat disimpulkan bahwa pembelajaran statistika pada umumnya berada pada kualitas menarik perhatian mahasiswa..

Gambaran respon mahasiswa terhadap pembelajaran statistika di program studi Pendidikan Agama Islam Universitas Muslim Indonesia, dapat dilihat pada Gambar 4.

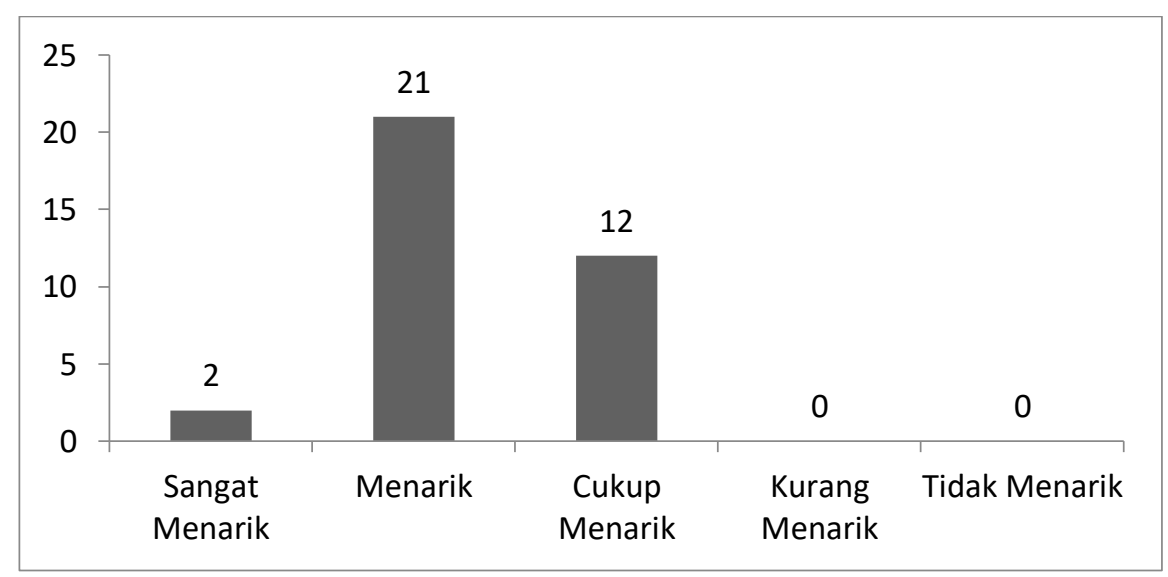

Gambar 4. Diagram Respon Mahasiswa terhadap Pembelajaran Statistika

Rangkuman hasil angket mahasiswa terhadap pembelajaran statistika, dapat di perlihatkan pada Tabel 6. 
Tabel 6 Rangkuman Hasil Angket Respon Mahasiswa terhadap Pembelajaran Statistika

\begin{tabular}{llccccc}
\hline \multirow{2}{*}{ No. } & \multirow{2}{*}{ Aspek } & Rata- & \multicolumn{4}{c}{ Persentase } \\
\cline { 4 - 6 } & & rata & Menarik & $\begin{array}{c}\text { Sangat } \\
\text { Menarik }\end{array}$ & $\begin{array}{c}\text { Jumlah } \\
(\mathbf{\%})\end{array}$ & Keputusan \\
\hline 1 & Kognitif & 62,1 & 54 & 6 & 60 & Menarik \\
2 & Afektif & 72,4 & 51 & 29 & 80 & Menarik \\
3 & Psikomotorik & 66,1 & 49 & 23 & 72 & Menarik \\
\hline & Total & 65,71 & 6 & 60 & 66 & Menarik \\
\hline
\end{tabular}

Berdasarkan Tabel 6, dapat dijelaskan bahwa respon mahasiswa terhadap pembelajaran statistika setelah digabungkan persentase menarik dan sangat menarik yaitu, pada aspek kognitif diperoleh ratarata 62,1 dengan persentase $60 \%$, aspek afektif diperoleh rata-rata 72,4 dengan persentase $80 \%$, aspek psikomotorik diperoleh rata-rata 66,1 dengan persentase $72 \%$, dan aspek total di peroleh rata-rata 65,71 dengan rata-rata 77\%, sehingga respon mahasiswa terhadap pembelajaran statistika berada pada respon positif dengan menunjukkan kualitas pembelajaran yang menarik.

\section{Kesimpulan}

Berdasarkan pembahasan dapat disimpulkan bahwa respon mahasiswa di tinjau dari aspek kognitif menunjukkan respon yang positif sebesar $60 \%$, aspek afektif menunjukkan respon positif sebesar $80 \%$, dan aspek psikomotorik menunjukkan respon positif sebesar $72 \%$, sehingga dapat disimpulkan bahwa respon mahasiswa terhadap pembelajaran statistika mahasiswa program studi pendidikan agama Islam fakultas Agama Islam Universitas Muslim Indonesia berada pada respon yang positif dengan menunjukkan kualitas pembelajaran statistika yang menarik. Peneliti menyarankan agar pembelajaran statistika lebih menarik lagi, aspek kognitif dan aspek psikomotorik mahasiswa perlu di tingkatkan lagi.

\section{Referensi}

Arikunto, S. (2016). Dasar-dasar evaluasi pendidikan. Jakarta: Bumi Aksara.

Bruce, J., Marsha, W., Emily, C., Fawaid, A., \& Mirza, A. (2011). Models of teaching: modelmodel pengajaran (ke-8). Yogyakarta: Pustaka Pelajar.

Cobb, G. (1992). Teaching statistics, (heeding the call for change: suggestions for curricular action). Mathematical Association of America.

delMas, R. C. (2002). Statistical literacy, reasoning and learning: A commentary. Journal of Statistics Education, 10(3). https://doi.org/10.1080/10691898.2002.11910679

Moore, D. S. (1997). New pedagogy and new content: the case of statistics. International Statistical Review / Revue Internationale de Statistique, 65(2), 123. https://doi.org/10.2307/1403333 
Sanjaya, W. (2008). Strategi pembelajaran berorientasi standar proses pendidikan. Kencana.

Slameto. (2013). Belajar dan faktor-faktor yang mempengaruhinya. Jakarta: Rineka Cipta.

Sugiyono. (2013). Metode penelitian kuantitatif, kualitatif, dan $R \& D$. Bandung: Alfabeta.

Syah, M. (2013). Psikologi belajar. Jakarta: Rajawali Pers.

Tiro, M. A. (2017). Teaching statistics in Indonesia school: today and future. ISI Regional Statistics Conference.

Tjalla, A. (2010). Potret mutu pendidikan Indonesia ditinjau dari hasil-hasil studi internasional. Seminar Nasional FKIP-UT, 3, 1-22. http://pustaka.ut.ac.id/pdfartikel/TIG601.pdf

Wahab, A. (2013). Statistika I dasar-dasar statistika deskriptif untuk ilmu pendidikan dan sains. Yogyakarta: Kaukaba Dipantara.

Wahab, A. (2017). Pengembangan modul pembelajaran literasi statistika (analisis regresi linier sederhana dengan R). Disertasi Universitas Negeri Makassar.

Wahab, A., Mahmud, A., \& Tiro, M. A. (2018). The effectiveness of a learning module for statistical literacy. New Educational Review, 53(3), 187-200.

https://doi.org/10.15804/tner.2018.53.3.16

Wahab, A., Syahid, A., \& Junaedi. (2021). Penyajian data dalam tabel distribusi frekuensi dan aplikasinya pada ilmu pendidikan. Education and Learning Journal, 2(1), 40-48. https://doi.org/10.33096/eljour.v2i1.91 